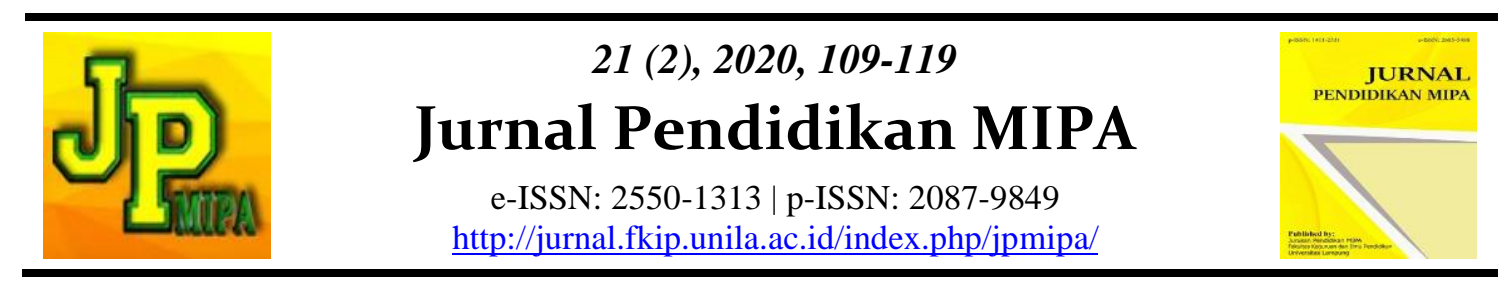

\title{
Problem-Based Learning Assisted by Mathematics Kit to Increase Students' Mathematical Understanding and Mathematical Disposition
}

\author{
Achmad Mudrikah ${ }^{1}$, Nandang Arif Saefuloh ${ }^{1}$, Abdorrakhman Gintings $^{2}$ \\ ${ }^{1}$ Department of Mathematics Education, Universitas Islam Nusantara, Indonesia \\ ${ }^{2}$ Department of Special Education, Universitas Islam Nusantara, Indonesia
}

\begin{abstract}
This research intends to reveal the increasing of senior high school students' mathematical understanding and mathematical disposition. The study involved 124 students from ordinary private schools and Islamic boarding private school. The research method used was quasi-experiment pretest and posttest control group design. The research goals are to examine students' mathematical understanding ability and mathematical dispositions based on the type of school, type of learning, and students' prior mathematical abilities. The results showed that mathematical understanding and mathematical dispositions of students who received problembased learning assisted by mathematics kit (PBL-MK) was better than students who only received PBL. Islamic boarding schools students can show better mathematical understanding when studying with PBL-MK. Islamic boarding school students who have high and medium prior mathematical abilities gain better mathematical understanding than non-boarding school students.
\end{abstract}

Keywords: problem-based learning, mathematics kit, mathematical understanding, mathematical disposition.

Abstrak: Penelitian ini bertujuan untuk mengungkap peningkatan kemampuan pemahaman konsep matematik dan disposisi matematik siswa SMA. Penelitian ini melibatkan 124 siswa dari sekolah swasta biasa dan sekolah swasta yang dikelola oleh pesantren. Metode penelitian dan disain penelitian yang digunakan adalah quasi-experiment pretest and posttest control group design. Tujuan penelitian adalah untuk menguji kemampuan pemahaman konsep matematik dan disposisi matematik siswa berdasarkan jenis sekolah, jenis pembelajaran dan kemampuan awal matematik siswa. Hasil penelitian menunjukkan bahwa kemampuan pemahaman konsep matematika dan disposisi matematik siswa yang menggunakan pembelajaran berbasis masalah berbantuan kit matematika (PBL-MK) lebih baik daripada siswa yang hanya mendapatkan PBL tanpa menggunakan kit matematika. Siswa dari pondok pesantren dapat menunjukkan pemahaman konsep matematika yang lebih baik melalui PBL-MK berbantuan kit matematika. Siswa dengan kemampuan awal tinggi dan sedang dari SMA swasta pesantren memperoleh pemahaman konsep matematika yang lebih baik dibandingkan siswa dari sekolah swasta non pesantren.

Kata kunci: pembelajaran berbasis masalah, kit matematika, pemahaman matematik, disposisi matematik.

Mudrikah et al.

Email: achmadmudrikah@uninus.ac.id
DOI: http://dx.doi.org/10.23960/jpmipa/v21i2.pp109-119

Received: 28 October 2020

Accepted: 30 November 2020 


\section{- INTRODUCTION}

Mathematical understanding and mathematical disposition are two of the various abilities that high school students who study mathematics should achieve. The ability to understand mathematical concepts which can help students to prevent them from making big mistakes which is the principle, will make students have a more positive attitude towards mathematics (National Research Council, 2001). Students who already have an understanding of mathematical concepts according to the National Center for Education Statistics will have the following abilities: 1) can conceptualize, label concepts, and provide examples of concepts; 2) can connect all models, diagrams, concept manipulation and various representations of concepts; 3) Identify and apply principles; 4) see and apply facts and definitions; 5) comparing, differentiating, and integrating related concepts and concepts; 6) concept, interpret, and apply signs and symbols and terms used to represent concepts. With their understanding of this conceptual understanding, students have the ability to determine which are applied carefully to the definition of a concept, conceptual relationship or representation of these definitions and relationships.

The conditions that occur in students who already have the ability to understand the concepts, will encourage an increase in their mathematical disposition. Because mathematical disposition itself according to Lin \& Tai (2016) is an ability that can affect their learning and usually can explain how well students can motivate themselves in dealing with their learning difficulties. Thus, the two abilities mentioned above are very important because they will have a positive impact on student mathematics learning outcomes. Especially if we look at the current condition which shows the fact that during the learning process at school, students tend to have negative attitudes towards mathematics learning (Hijon, 2017).

The lessons that can be used in an effort to improve the understanding of mathematical concepts and mathematical dispositions of students, of course vary. The choice is very much dependent on the teacher's experience when they feel that the learning used can be done effectively and efficiently in supporting the achievement of goals. Through their experience, teachers should become effective teachers who will make his students have the ability to use mathematics as a tool to solve problems in their everyday life. When students have been able to do this, it is expected that they will view mathematics as something relevant and interesting (Oros et al., 2015).

Problem-based learning (PBL) is a learning model that is often used by mathematics teachers in Indonesia in carrying out the learning process in the classroom. Various studies have shown that PBL can improve high order thinking skills of high school students (Mudrikah, 2017; Surya \& Syahputra, 2017); Students' mathematical creative thinking skills (Maskur et al., 2020), problem solving abilities (Hendriana et al., 2018), as an effort to determine high school students' mathematical thinking skills (Mustafa et al., 2019), can show high school students' ability to explain various issues and analyze the influence of context and assumptions as part of indicators critical thinking skills (Siriwat \& Katwibun, 2017). In terms of students' affective abilities, PBL is also able to make students have high levels of self-regulated learning (Siriwat \& Katwibun, 2017), Self-Beliefs (Sangkaew \& Katwibun, 2017) and self-confidence (Hendriana et al., 2018).

Students' solving problems related to daily life in PBL, requires using both previous knowledge and existing knowledge within them (Sockalingan, N. et al., 2011). This condition makes students have the ability to be able to think abstractly, think creatively, think critically, problem solving, increase motivation and achievement of learning outcomes as well as encouragement to participate actively in group and individual 
discussions (Jamal et al., 2019). According to Duch et al. (2001) Problem-based instruction addresses directly many of the recommended and desirable outcomes, specifically the ability to think critically and be able to analyze and solve complex, real world problems; to find, evaluate, and use appropriate learning resources; to work in teams and small groups; to demonstrate versatile and effective communication skills, both verbal and written; and to use content knowledge and intellectual skills.

Effectiveness of student-centered teaching of mathematics depends on the use of media (Krishnasamy et al., 2014). However, this will be greatly influenced by the perceptions of teachers regarding the media itself. The findings of the research of Krishnasamy (2014) which states that there is a positive relationship between teachers' perceptions and the use of media in mathematics learning reinforces the impression that whatever media is used depends on the desire of the teachers to use it in learning.

Mathematics conceptual understanding is the ability to understand concepts, oration and relation in mathematics (Laswadi et al., 2016). The ability to understand mathematical concepts needs to be developed in the learning process so that students can develop an optimal understanding of the mathematics subject matter they are studying. Students who have acquired the ability to understand mathematical concepts have a great opportunity to be able to master various competencies that the teacher wants to teach in the classroom (Suarsana et al., 2018). Indonesian students tend to have low concept comprehension skills so that they cannot solve problems related to everyday life even though they are included in students who succeed in learning mathematics (Hidayat \& Iksan, 2015). If it is related to the APOS theory presented by Dubinsky (Arnon et al., 2013) that Interiorization and Encapsulation are the main mental mechanism for building the mental structures of APOS or action, process, object and schema, then Mathematics conceptual understanding of students is an ability that will be an important part of the interiorization and encapsulation process.

Disposition is a tendency to often show consciously and voluntarily a pattern of behavior aimed at a big goal. There are several reasons that lead us to argue that dispositions should be included among educational goals. As noted by Katz (1993), these reasons consist of: (1) That the proficiency of knowledge and skills does not guarantee that they can be used and applied; (2) Considering dispositions is important because the learning process by acquiring some knowledge and skills can damage or reduce the disposition itself to use them; (3) Some important dispositions relevant to education, such as the disposition to investigate, can be thought of as innate; (4) The process of selecting curriculum and teaching strategies should include paying attention to how desirable dispositions can be strengthened and undesirable dispositions weakened; (5) The disposition is less likely to be acquired through a didactic process than it is to be modeled by young children when they are around people showing them off.

Disposition pays attention not only to attitudes but also to the tendency to think and act in positive ways. The students' mathematical disposition is manifested in the way they approach tasks -whether with confidence, a willingness to explore alternatives, persistence, and interest - and in their tendency to reflect on their own thinking (NCTM, 1989). Students' mathematical disposition abilities could be improved through the selection of appropriate learning strategies. The use of appropriate learning tools with appropriate strategies that enable students to build their own knowledge can develop their mathematical disposition abilities (Sari \& Darhim, 2020). In other studies, it was said that, the benefit of developing students' mathematical disposition abilities would increase their mathematical power (Kusmaryono et al., 2019). Mental functions in the form of 
cognitive, affective, and connative functions will consistently contribute when mathematical dispositions have been developed. Meanwhile in (Yaniawati et al., 2019) it is said that mathematical dispositions can arise when students complete the mathematical tasks that are carried out with confidence, responsibility, diligence, do not give up easily, feel challenged, have a desire to look for other ways and reflect on the ways of thinking that has been done. The learning that is given properly and effectively turns out to be able to develop students' mathematical disposition abilities.

\section{- METHOD}

This study involved 124 students of class XI from two private high schools, one of which is a private school managed by an Islamic boarding school. From the two schools, 2 classes were each selected to be given problem-based learning assisted by a simple mathematics kit as an experimental class and problem-based learning without the help of a mathematics kit as the control class. Population of this study were all eleventh grade students in both schools. Random sample selection was only carried out for each of the 2 classes in the two existing schools. Thus, the conclusions cannot be generalized about all of the schools in Indonesia.

In each school, the control group pretest-posttest experimental design was applied. The pretest and posttest questions consist of essay questions about mathematics conceptual understanding ability on the material of sequences and series and questionnaires about mathematical dispositions. All classes are given a prior mathematical ability (PMA) test which contains questions about the prerequisite abilities that have been obtained in the previous class, to classify their students into high, medium and low ability categories.

The PMA test, Mathematics conceptual understanding test and mathematical disposition questionnaires were previously validated by five validators who were considered experts in mathematics education. Validators are asked to assess or consider and provide suggestions and input regarding the content validity and face validity of all three instruments. Content validity considerations are based on the suitability of items or statements with the subject matter to be revealed, indicators of every aspect and aspect of students' abilities or attitudes related to the abilities and dispositions to be measured. Face validity considerations are based on the clarity of the statement in terms of language or redaction. To test the uniformity of the results of the content validity and face validity considerations of the five validators, the Q-Cochran statistical test was performed. To determine the reliability of the three instruments, a trial was conducted on 30 high school students. Trial analysis of the three instruments can produce a reliability coefficient that can be used as a benchmark to determine the reliability category of the three instruments.

For mathematical dispositions, the scoring of the response responses consisting of 5 responses includes Very frequent, frequent, occasional, rare and very rare, response scaling methods are used. With this method, the location of the response point is obtained on the continuum which is the score for the response in question.

\section{- RESULT AND DISCUSSION}

Statistical results of Students' Mathematics Conceptual Understanding (MCU) and students' Mathematical Disposition (MD) are on Table 1, Table 2, Table 3, and Table 4. The Tables show that learning factor tends to give higher MCU achievement and n-gain than school category and prior mathematical ability (PMA). 
Table 1. Students' MCU based on school category and PMA after PBL-MK and PBL implementation

\begin{tabular}{|c|c|c|c|c|c|c|c|c|c|c|c|c|c|}
\hline \multirow{3}{*}{$\begin{array}{c}\text { School } \\
\text { Category }\end{array}$} & \multirow{3}{*}{ PMA } & \multicolumn{6}{|c|}{$\begin{array}{l}\text { Problem-Based Learning Assisted by } \\
\text { Math Kits }\end{array}$} & \multicolumn{6}{|c|}{ Problem-Based Learning } \\
\hline & & \multicolumn{2}{|c|}{ Pretest } & \multicolumn{2}{|c|}{ Posttest } & \multirow{2}{*}{ Gain } & \multirow{2}{*}{$\mathbf{n}$} & \multicolumn{2}{|c|}{ Pretest } & \multicolumn{2}{|c|}{ Posttest } & \multirow{2}{*}{ Gain } & \multirow{2}{*}{$\mathbf{n}$} \\
\hline & & $\mathbf{r}$ & $\mathbf{s}$ & $\mathbf{r}$ & $\mathbf{s}$ & & & $\mathbf{r}$ & $\mathbf{s}$ & $\mathbf{r}$ & $\mathbf{s}$ & & \\
\hline \multirow{4}{*}{$\begin{array}{c}\text { Non- } \\
\text { Boarding } \\
\text { School }\end{array}$} & High & 15.80 & 3.03 & 50.60 & 18.51 & 0.63 & 5 & 9.50 & 2.92 & 51.25 & 19.10 & 0.68 & 4 \\
\hline & Medium & 12.05 & 3.20 & 39.95 & 2.63 & 0.47 & 21 & 6.65 & 2.59 & 34.59 & 12.38 & 0.44 & 17 \\
\hline & Low & 11.20 & 4.04 & 34.00 & 1.73 & 0.38 & 5 & 3.20 & 2.92 & 16.40 & 19.10 & 0.19 & 10 \\
\hline & Sub Total & 12.52 & 3.60 & 40.71 & 5.56 & 0.48 & 31 & 5.90 & 2.80 & 30.87 & 14.79 & 0.39 & 31 \\
\hline \multirow{4}{*}{$\begin{array}{c}\text { Islamic } \\
\text { Boarding } \\
\text { School }\end{array}$} & High & 5.33 & 3.79 & 62.33 & 2.31 & 0.87 & 3 & 3.00 & 1.22 & 23.00 & 7.52 & 0.30 & 5 \\
\hline & Medium & 3.50 & 2.31 & 44.25 & 5.51 & 0.60 & 13 & 2.10 & 2.27 & 26.40 & 9.82 & 0.35 & 20 \\
\hline & Low & 1.88 & 1.94 & 14.75 & 5.42 & 0.19 & 16 & 3.00 & 2.74 & 20.00 & 8.51 & 0.25 & 5 \\
\hline & Sub Total & 2.78 & 2.45 & 31.22 & 18.15 & 0.42 & 32 & 2.40 & 2.19 & 24.77 & 9.34 & 0.32 & 30 \\
\hline \multirow{4}{*}{ Total } & High & 11.88 & 6.22 & 55.00 & 6.28 & 0.72 & 8 & 5.89 & 3.59 & 35.56 & 16.42 & 0.47 & 9 \\
\hline & Medium & 8.71 & 5.21 & 41.62 & 4.42 & 0.58 & 34 & 4.19 & 3.20 & 30.16 & 11.34 & 0.39 & 37 \\
\hline & Low & 4.10 & 4.75 & 19.33 & 9.60 & 0.23 & 21 & 3.38 & 2.00 & 17.60 & 6.34 & 0.21 & 15 \\
\hline & Total & 7.57 & 5.77 & 35.89 & 0.35 & 0.48 & 63 & 4.18 & 3.06 & 27.87 & 12.69 & 0.36 & 61 \\
\hline
\end{tabular}

Learning factor has given higher MCU achievement and n-gain than school category because of Non Boarding School (NBS) of Problem-Based Learning Assisted by Simple Mathematics Kits (PBL-MK) get almost similar n-gain of MCU (posttest = 40.71 and n-gain $=0.48$ ) with Islamic Boarding School (IBS) of PBL-MK (posttest $=$ 31.22 and n-gain $=0.42$ ) but get higher posttest score and n-gain of MCU than NBS of Problem-Based Learning $(\mathrm{PBL})$ (posttest $=30.87$ and n-gain $=0.39$ ) and IBS of PBL (posttest $=24.77$ and $n$-gain $=0.32$ ). According to learning factor, the enhancement and the achievement of Students' MCU that acquire learning in PBL-MK (posttest $=35.89$ and $n$-gain $=0.48$ ) tends to get higher than the students that acquire PBL (posttest $=27.87$ and $\mathrm{n}$-gain $=0.36$ ).

Table 2. Students' mathematical disposition based on school category and prior mathematical ability after PBL-MK and PBL implementation

\begin{tabular}{|c|c|c|c|c|c|c|c|c|c|c|c|c|c|}
\hline \multirow{3}{*}{$\begin{array}{c}\text { School } \\
\text { Category }\end{array}$} & \multirow{3}{*}{ PMA } & \multicolumn{6}{|c|}{$\begin{array}{l}\text { Problem-Based Learning Assisted by } \\
\text { Math Kits }\end{array}$} & \multicolumn{6}{|c|}{ Problem-Based Learning } \\
\hline & & \multicolumn{2}{|c|}{ Pretest } & \multicolumn{2}{|c|}{ Posttest } & \multirow{2}{*}{ Gain } & \multirow{2}{*}{$\mathbf{n}$} & \multicolumn{2}{|c|}{ Pretest } & \multicolumn{2}{|c|}{ Posttest } & \multirow{2}{*}{ Gain } & \multirow{2}{*}{$\mathbf{n}$} \\
\hline & & $\mathbf{r}$ & $\mathbf{S}$ & $\mathbf{r}$ & $\mathbf{s}$ & & & $\mathbf{r}$ & $\mathbf{s}$ & $\mathbf{r}$ & $\mathbf{s}$ & & \\
\hline \multirow{5}{*}{$\begin{array}{c}\text { Non- } \\
\text { Boarding } \\
\text { School }\end{array}$} & High & 92.00 & 7.07 & 108.00 & 8.22 & 0.23 & 5 & 99.00 & 6.98 & 103.25 & 8.14 & 0.07 & 4 \\
\hline & Medium & 84.57 & 8.19 & 98.19 & 11.06 & 0.18 & 21 & 95.53 & 12.56 & 102.59 & 10.42 & 0.10 & 17 \\
\hline & Low & 81.20 & 8.32 & 93.60 & 8.85 & 0.16 & 5 & 86.20 & 7.91 & 97.80 & 11.44 & 0.16 & 10 \\
\hline & Sub & & & & & & & & & & & & \\
\hline & Total & 85.23 & 8.44 & 99.03 & 10.94 & 0.19 & 31 & 92.97 & 11.47 & 101.13 & 10.46 & 0.12 & 31 \\
\hline \multirow{5}{*}{$\begin{array}{c}\text { Islamic } \\
\text { Boarding } \\
\text { School }\end{array}$} & High & 90.33 & 9.45 & 122.33 & 9.29 & 0.46 & 3 & 103.60 & 5.18 & 108.80 & 5.45 & 0.09 & 5 \\
\hline & Medium & 85.15 & 11.05 & 111.92 & 7.61 & 0.35 & 13 & 92.45 & 10.71 & 102.65 & 11.19 & 0.15 & 20 \\
\hline & Low & 83.81 & 10.96 & 106.63 & 6.61 & 0.29 & 16 & 92.00 & 18.71 & 105.40 & 11.01 & 0.17 & 5 \\
\hline & Sub & & & & & & & & & & & & \\
\hline & Total & 84.90 & 10.78 & 109.87 & 8.51 & 0.32 & 32 & 94.23 & 12.06 & 104.13 & 10.41 & 0.14 & 30 \\
\hline \multirow{4}{*}{ Total } & High & 91.38 & 7.41 & 113.38 & 10.88 & 0.32 & 8 & 101.56 & 7.41 & 106.33 & 10.88 & 0.07 & 9 \\
\hline & Medium & 84.79 & 9.12 & 103.44 & 12.01 & 0.24 & 34 & 93.86 & 11.54 & 102.62 & 10.70 & 0.13 & 37 \\
\hline & Low & 83.19 & 10.25 & 103.52 & 8.99 & 0.26 & 21 & 88.13 & 12.18 & 100.33 & 11.51 & 0.16 & 15 \\
\hline & Total & 85.10 & 9.53 & 104.73 & 11.28 & 0.26 & 63 & 93.59 & 11.68 & 102.61 & 10.46 & 0.13 & 61 \\
\hline
\end{tabular}

Learning factor has given higher MD achievement and n-gain than school category because of Non Boarding School (NBS) of Problem-Based Learning Assisted by Simple Mathematics Kits (PBL-MK) get almost similar n-gain of MD (posttest $=99.03$ and ngain $=0.19$ ) with Islamic Boarding School (IBS) of PBL-MK (posttest $=109.87$ and ngain $=0.32$ ) and also similar with posttest score and n-gain of MD NBS of ProblemBased Learning $(\mathrm{PBL})$ (posttest $=101.13$ and $\mathrm{n}$-gain $=0.12$ ) and IBS of PBL (posttest $=$ 104.13 and n-gain $=0.14)$. According to learning factor, the enhancement and the 
achievement of Students' MD that acquire learning in PBL-MK (posttest $=104.73$ and ngain $=0.26$ ) tends to get higher than the students that acquire PBL (posttest $=102.61$ and n-gain $=0.13$ ).

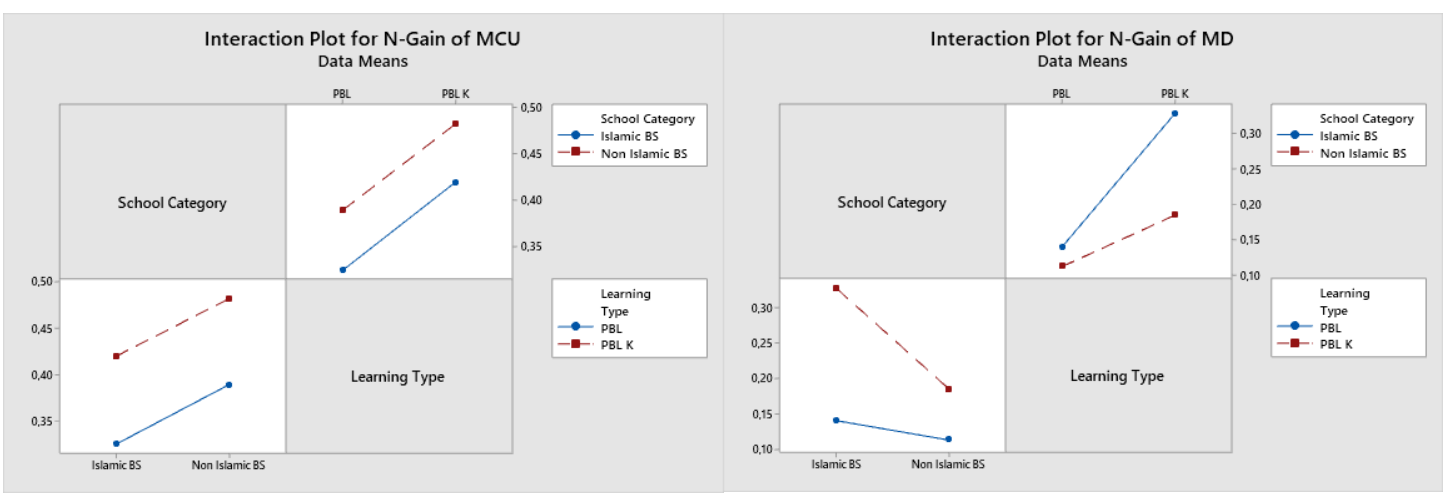

Figure 1. Interaction plot of learning type and school category for n-gain of MCU and MD

From the two ways ANAVA of MCU test and MD n-gain with learning and school category factors and Figure 1, we can conclude that there is no significantly different between MCU test n-gain based on School Category and there is no interaction between School Category and learning type of MCU test n-gain. We also can conclude that MCU test n-gain are significantly different based on learning type; MD n-gain are significantly different based on school category; and there is an interaction between school category and learning type of MD n-gain.

From the t-test and Mann Whitney test of Mathematical Conceptual Understanding n-gain and Mathematical Disposition n-gain based on learning and school category factors, it can be concluded that the MCU Test n-gain and MD Test n-gain for learning PBL-MK and PBL are significantly different. Likewise, the MCU Test n-gain and MD Test n-gain for Non Boarding Schools and Islamic Boarding Schools are significantly different.

From the t-test and Mann Whitney test of Mathematical Conceptual Understanding n-gain and Mathematical Disposition n-gain between two Learning types on Students form Non-boarding school and Students form Islamic Boarding School, it can be concluded that the MD Test at the Non-Boarding School and the Islamic Boarding School between students who received PBLK and students who received PBL was significantly different. Meanwhile, the MCU Test in the two types of schools between students who received PBLK and students who received PBL did not significantly different.

Table 3. Mann-Whitney test and t-test of MCU n-gain and MD n-gain between school categories on PBL-MK and PBL

\begin{tabular}{ccccccc}
\hline \multirow{2}{*}{ Learning } & $\begin{array}{c}\text { Comparison of School } \\
\text { Category }\end{array}$ & n-gain & $\mathbf{t}$ & $\mathbf{W}$ & $\mathbf{P}$ & $\mathbf{H}_{\mathbf{0}}$ \\
\hline \multirow{2}{*}{ PBL-MK } & NBS and IBS & MCU Test & - & 1053.50 & 0.402 & Accepted \\
\cline { 2 - 7 } & NBS and IBS & MD Test & -5.84 & - & 0.000 & Rejected \\
\hline \multirow{2}{*}{ PBL } & NBS and IBS & MCU Test & - & 1044.50 & 0.231 & Accepted \\
\cline { 2 - 7 } & NBS and IBS & MD Test & -1.03 & - & 0,307 & Accepted \\
\hline
\end{tabular}


From the data in Table 3, it can be concluded that the MD Test of students who received PBL-MK between Non-Boarding School and Islamic Boarding School students is significantly different. Meanwhile, for the MCU Test, students who received PBLK and students who received PBL did not significantly different.

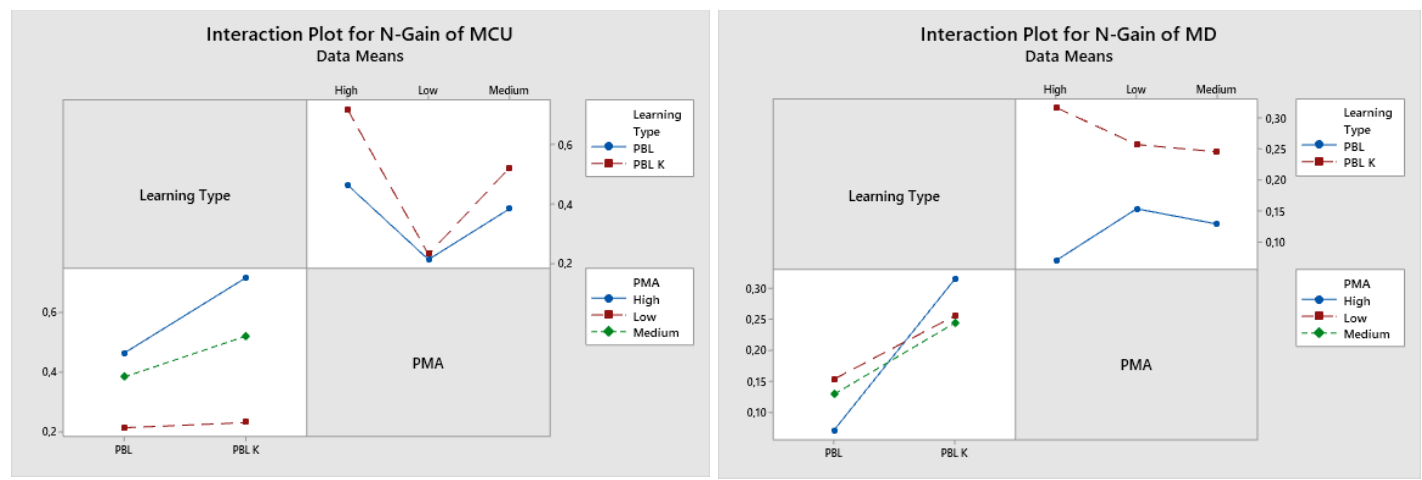

Figure 2. Interaction plot of learning and PMA for n-gain of MCU and MD

From Two Way Anava of MCU n-gain and MD n-gain With learning Factor and PMA Factor and Figure 2, we can conclude that MCU test n-gain are significantly different based on Students' PMA and learning type, but there is no interaction between PMA and learning type of MCU test n-gain. We also can conclude that MD test n-gain are significantly different based on learning type but doesn't significantly different based on PMA. There is no interaction between PMA and learning type of MD n-gain.

Table 4. Mann-Whitney test or t-test of MCU n-gain and MD n-gain between PMA categories from two learning types

\begin{tabular}{|c|c|c|c|c|c|c|}
\hline Learning Type & $\begin{array}{l}\text { n- } \\
\text { gain }\end{array}$ & $\begin{array}{c}\text { PMA } \\
\text { Comparison }\end{array}$ & $\mathbf{T}$ & W & $\mathbf{P}$ & $\mathbf{H}_{\mathbf{0}}$ \\
\hline \multirow{6}{*}{$\begin{array}{l}\text { Problem-Based Learnig } \\
\text { Assisted by Simple } \\
\text { Mathematics Kit }\end{array}$} & \multirow{3}{*}{$\begin{array}{l}\text { MCU } \\
\text { Test }\end{array}$} & $\begin{array}{l}\text { High and } \\
\text { Medium }\end{array}$ & 4.06 & - & 0.004 & Rejected \\
\hline & & High and Low & - & 204.00 & 0,000 & Rejected \\
\hline & & Medium and Low & - & 1301.00 & 0,000 & Rejected \\
\hline & \multirow{3}{*}{$\begin{array}{l}\text { MD } \\
\text { Test }\end{array}$} & $\begin{array}{l}\text { High and } \\
\text { Medium }\end{array}$ & 1.29 & - & 0.229 & Accepted \\
\hline & & High and Low & - & 351.00 & 0.219 & Accepted \\
\hline & & Medium and Low & - & 1156.00 & 0.000 & Rejected \\
\hline \multirow{6}{*}{$\begin{array}{l}\text { Problem-Based } \\
\text { Learning }\end{array}$} & \multirow{3}{*}{$\begin{array}{c}\text { MCU } \\
\text { Test }\end{array}$} & $\begin{array}{l}\text { High and } \\
\text { Medium }\end{array}$ & 0.93 & - & 0,375 & Accepted \\
\hline & & High and Low & - & 160.50 & 0,005 & Rejected \\
\hline & & Medium and Low & - & 1154.00 & 0.469 & Accepted \\
\hline & \multirow{3}{*}{$\begin{array}{l}\text { MD } \\
\text { Test }\end{array}$} & $\begin{array}{l}\text { High and } \\
\text { Medium }\end{array}$ & -1.55 & - & 0.146 & Accepted \\
\hline & & High and Low & -2.23 & - & 0.039 & Rejected \\
\hline & & Medium and Low & -1.15 & - & 0.261 & Accepted \\
\hline
\end{tabular}

From table 4, it can be concluded that the mathematics conceptual understanding ability in the class that receives problem-based learning assisted by a simple mathematics kit is significantly different for all PMA students. Meanwhile, for the PBL class, it only significantly different for the comparison between the high and low PMA classes. For 
Mathematical Disposition in PBL-MK class, it only significantly different for the comparison between medium and low PMA. Meanwhile, in the PBL class, only high PMA and low PMA is significantly different.

The results of the research which states that learning factors tend to give higher MCU and MD achievement and n-gain than school category and PMA, show that the use of problem-based learning with the help of a simple math kit (PBL-MK) has a better impact than PBL without the help of a kit. simple math. This is in line with the statement that learning media is needed in creating a quality learning process for students (Krishnasamy, H. N. et al., 2014). Although the media referred to Krishnasamy, H. N., et al. (2014) is more about the use of ICT, the use of mathematics kits deserves the attention of teachers. The advantage of a simple math kit is that it is easier to create it so that it is considered more suitable for teachers in Indonesia. For the students themselves, the use of this simple math kit is expected to be one of the factors that can develop their resilience in learning mathematics. Thus the achievement self-expectations of students that are shown as the strongest and most influential variable to develop their resilience (Hijon, A. C. 2017) have occurred in this study. The results of the research which states that learning factors tend to give higher MCU achievement and n-gain, shows that the enhancement and the achievement of Students' MCU that acquire learning in PBL-MK tends to get higher than the students that acquire PBL. This condition shows that evident from research which reveals that students still have difficulty expressing their opinions and drawing conclusions (Siriwat, R., \& Katwibun, D. 2017) after obtaining the PBL model, can be resolved with the help of a simple math kit. A simple mathematics kit can help the learning process along with the scaffolding delivered by the teacher, especially at the process and object stages in APOS theory (Arnon, I., et al. 2013). Interiorization and encapsulation processes are greatly assisted by the existence of a simple mathematical kit and scaffolding provided by the teacher so that students can gain better understanding of mathematics conceptual understanding than without using a mathematical kit.

Statement from research of Laswadi, et. al. (2016) which states that students should be given the opportunity to build their own definition, rules, models and procedures in order to obtain the expected conceptual understanding has been proven in this study. In this study, students through a problem-based learning model assisted by a simple mathematics kit received learning materials for sequences and series. The math kit they got is shown in Figures 5 and Figure 6.
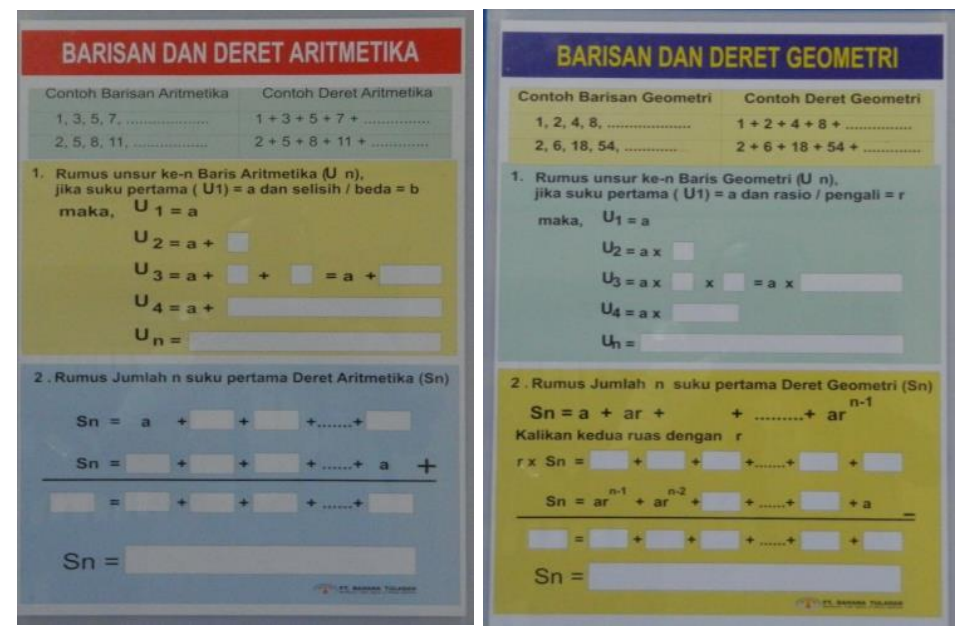

Figure 3. Arithmetic and geometric sequences and series mathematics kit 
After students are given daily problems related to the sequence and series material, they are asked to have a discussion using a math kit. Through this math kit, students have received the opportunity to build their own definition, rules, models and procedures in order to obtain conceptual understanding of arithmetic and geometric sequences and series.

Learning factor has given higher MD achievement and n-gain than school category. According to learning factor, the enhancement and the achievement of Students' MD that acquire learning in PBL-MK tends to get higher than the students that acquire PBL. This finding confirms that the learning process in the PBL-MK class is better able to increase the students' self-confidence, flexibility, persistence, interest and finding, monitoring and reflection, application and appreciation of the role of mathematics of students. The use of a simple mathematical kit has been able to create learning that makes students carry out the group discussion process more effectively in the sense that each of them has the confidence to express opinions while being flexible and willing to accept the opinions of their discussion partners. The mathematics kit is also able to bring out the curiosity of students in doing the assignments given in the worksheet given by the teacher. This situation has a positive impact on students 'persistence as well as students' interest and finding ability.

There is no significant difference between Students' MCU based on school category, indicating that MCU achievement and MCU n-gain are not influenced by differences in school categories. Meanwhile for MD, differences in school categories affect MD achievement and MD n-gain. The interaction between school category and learning type of MD n-gain strengthens the influence of this school category. Students who obtained PBL-MK at the Islamic boarding school showed marked improvements in MD compared to students in other classes. This is because the students in this class have been able to show their confidence, responsibility, diligence, do not give up easily, feel challenged, have a desire to look for other ways and reflect on the ways of thinking that has been done, when they are complete mathematical tasks that are carried out, as stated in Yaniawati, et. al. (2019). The math kit has helped teachers encourage students to complete their mathematical tasks independently through discussion in their respective groups. The use of mathematics Kit with PBL as a learning strategy has enabled students to build their own knowledge. This has developed their mathematical disposition abilities (Sari, D. P., \& Darhim. 2020).

MCU test n-gain are significantly different based on Students' PMA and learning type, but there is no interaction between PMA and learning type of MCU test n-gain. This shows that PMA students' and learning have an influence on improving MCU. In this study, Islamic boarding school students with high PMA who obtained PBL-MK obtained a better MCU improvement compared to Non Boarding School students with High PMA. Likewise, Islamic boarding school students who obtained PBL-MK with PMA medium received a better MCU improvement compared to Non Boarding School students with PMA medium. This condition reinforces the finding that Interiorization and Encapsulation are the main mental mechanism for building the mental structures of APOS or action, process, object and schema (Arnon, I., et al. 2013). Students' Mathematics conceptual who have High PMA have been able to properly construct APOS structures in themselves so that when they face complex problems related to the schema of the material they already have, they can solve the problem properly. 
The condition that MD tests n-gain are significantly different based on learning type but does not significantly different based on PMA, indicating that overall students who obtain PBL-MK get an increase in MD. This also shows that PBL-MK has been running effectively in developing students' mathematical disposition abilities.

\section{- CONCLUSION}

Mathematics conceptual understanding ability and mathematical dispositions of students who received problem-based learning assisted by simple mathematics kit was better than students who only received problem-based learning without assictance of mathematics kit. Students from Islamic boarding schools can show better understanding of mathematical concepts when studying mathematics with problem-based learning assisted by simple math kits. Students from Islamic boarding school who have high and medium prior mathematical abilities gain better understanding of mathematical concepts than students from non-boarding private school.

\section{- REFERENCES}

Arnon, I., Cottrill, J., Dubinsky, E., Oktaç, A., Roa Fuentes, S., Trigueros, M., \& Weller, K. (2014). APOS theory: A framework for research and curriculum development in mathematics education. Springer Science \& Business Media.

Duch, B. J., Groh, S. E., \& Allen, D. E. (2001). The power of problem-based learning: A practical "how to" for teaching undergraduate courses in any discipline. Sterling, Virginia: Stylus Publishing, LLC

Hendriana, H. Johanto, T., \& Sumarmo, U. (2018). The role of problem-based learning to improve students' mathematical problem solving ability and self confidence. Journal on Mathematics Education, 9(2), 291-300.

Hidayat, R. \& Iksan, H. Z. (2015). The effect of realistic mathematics education on students' conceptual understanding of linear programming. Creative Education, 6. $2348-2445$.

Hijon, A. C. (2017). The mathematics anxiety: A transtructural perspective. ProcediaSocial and Behavioral Sciences, 237, 1061-1065.

Jamal, S. N. B., Ibrahim, N. H. B., \& Surif, J. B. (2019). concept cartoon in problembased learning: A systematic literature review analysis. Journal of Technology and Science Education, 9(1), 51 - 58

Katz, L. G. (1993). Dispositions as educational goals. ERIC Digest. ERIC Clearinghouse on Elementary and Early Childhood Education Urbana IL.

Krishnasamy, H. N., Veloo, A., \& Hooi, N. S. (2014). Perception of theachers towards media usage in teaching mathematics in secondary schools. Procedia-Social and Behavioral Sciences, 112, 1093 - 1098.

Kusmaryono, I., Suyitno, H., Dwijanto, D., \& Dwidayati, N. (2019). The effect of mathematical disposition on mathematical power formation: review of dispositional mental functions. International Journal of Instruction. 12(1). 343-356.

Laswadi, Kusumah, Y. S., Darwis, S., \& Afgani, J. D. (2016). Developing conceptual understanding and procedural fluency for junior high school students through model-facilitated learning. European Journal of Science and Mathematics Education. 4(1). 67-74.

Lin, S.W. \& Tai, W. C. (2016). A longitudinal study for types and changes of students' mathematical disposition. Universal Journal of Educational Research, 4(8), 19031911. 
Maskur, R., Sumarno, Rahmawati, Y., Pradana, K., Syazali, M., Septian, A., \& Palupi, E. K. (2020). The effectiveness of problem-based learning and aptitude treatment interaction in improving mathematical creative thinking skills on Curriculum 2013. European Journal of Educational Research, 9(1), 375-383.

Mudrikah, A. (2016). Problem-based learning associated by action-process-objectschema (APOS) theory to enhance students' high order mathematical thinking ability. International Journal of Research in Education and Science, 2(1), 125-135.

Mustafa, S. Sari, V, \& Baharullah. (2019). The implementation of mathematical problembased learning model as an effort to understand the high school students' mathematical thinking ability. International Education Studies, 12 (2), 117-123.

National Center for Education Statistics. https://nces.ed.gov/nationsreportcard/ mathematics/abilities.asp

National Council of Teachers of Mathematics. (1989). Principles and standards for school mathematics. Reston. VA: NCTM.National Center for Education Statistics. https://nces.ed.gov/nationsreportcard/mathematics/abilities.asp

National Research Council. (2001). Adding it up. Helping children learn mathematics. Washington, DC. The National Press.

Oros, C., Schiopu, R., Popescu, V., \& Oprea, D. J. (2015). Mathematical education improving methods for high school terminal classes. Procedia-Social and Behavioral Sciences, 191, 1528-1543.

Sangkaew, S., \& Katwibun, D. (2017). 11th grade students' self-beliefs in a mathematics problem-based learning (PBL) classroom. Proceeding of the 42th Annual conference of the Mathematics Education Research Group of Australasia Perth: MERGA, 620-627.

Sari, D. P., \& Darhim. (2020). Implementation of REACT strategy to develop mathematical representation, reasoning, and disposition ability. Journal on Mathematics Education. 11(1). 145-156.

Siriwat, R., \& Katwibun, D. (2017). Exploring critical thinking in a mathematics problem-based learning classroom. Proceeding of the 40th Annual conference of the Mathematics Education Research Group of Australasia, 474-481.

Siriwat, R., \& Katwibun, D. (2017). 11th grade students' self-regulated learning in a mathematics problem-based learning (PBL) classroom. Proceeding of the 40th Annual conference of the Mathematics Education Research Group of Australasia, 420-427.

Sockalingam, N., Rotgans, J., \& Schmidt, H.G. (2011). Student and tutor perceptions on attributes of effective problems in problem-based learning. Higher Education, 62(1), 1-16.

Suarsana, I. M., Widiasih, N. P. S., \& Suparta, I. N. (2018). The effect of brain based learning on second grade junior students' mathematics conceptual understanding on polyhedron. Journal on Mathematics Education. 9(1). 145-156.

Surya, E. \& Syahputra, E. (2017). improving high-level thinking skills by development of learning PBL approach on the learning mathematics for senior high school students. International Education Studies, 10(8), 12-20.

Yaniawati, P. R., Indrawan, R., \& Setiawan, G. (2019). Core model on improving mathematical communication and connection, analysis of students' mathematical disposisiton. International Journal fo Instruction, 12(4). 639-648. 